\title{
Characterization of mouse sperm TMEM190, a small transmembrane protein with the trefoil domain: evidence for co-localization with IZUMO1 and complex formation with other sperm proteins
}

\author{
Hitoshi Nishimura ${ }^{1}$, Surabhi Gupta ${ }^{2}$, Diana G Myles ${ }^{2}$ and Paul Primakoff ${ }^{1}$ \\ Departments of ${ }^{1}$ Cell Biology and Human Anatomy, School of Medicine and ${ }^{2}$ Molecular and Cellular Biology, \\ University of California Davis, Davis, California 95616, USA
}

Correspondence should be addressed to H Nishimura who is now at Department of Biology, Emory University, Atlanta, Georgia 30322,USA; Email: hnishim@emory.edu

\begin{abstract}
TMEM190, a small transmembrane protein containing the trefoil domain, was previously identified by our proteomic analysis of mouse sperm. Two structural features of TMEM190, 'trefoil domain' and 'small transmembrane protein', led us to hypothesize that this protein forms a protein-protein complex required during fertilization, and we characterized TMEM190 by biochemical, cytological, and genetic approaches. We showed in this study that the mouse Tmem190 gene exhibits testis-specific mRNA expression and that the encoded RNA is translated into a 19-kDa protein found in both testicular germ cells and cauda epididymal sperm. Treatment of the cell surface with proteinase $\mathrm{K}$, subcellular fractionation, and immunofluorescence assay all revealed that mouse TMEM190 is an inner-acrosomal membrane protein of cauda epididymal sperm. During the acrosome reaction, TMEM190 partly relocated onto the surface of the equatorial segment, on which sperm-oocyte fusion occurs. Moreover, TMEM190 and IZUMO1, which is an immunoglobulin-like protein required for gamete fusion, co-localized in mouse sperm both before and after the acrosome reaction. However, immunoprecipitates of TMEM190 contained several sperm proteins, but did not include IZUMO1. These findings suggest that a mouse sperm protein complex(es) including TMEM190 plays an indirect role(s) in sperm-oocyte fusion. The role(s), if any, is probably dispensable since Tmem190-null male mice were normally fertile.

Reproduction (2011) 141 437-451
\end{abstract}

\section{Introduction}

Fertilization is a reproductive strategy to create a diploid zygote from two haploid gametes, which are usually a sperm and an oocyte. In mammals (Yanagimachi 1994), fertilization is initiated by sperm binding to the zona pellucida (ZP), an extracellular glycoprotein matrix surrounding the oocyte cell. The ZP-bound sperm penetrates through the $\mathrm{ZP}$, reaches the perivitelline space between the ZP and the oocyte, and binds to and fuses with the oocyte plasma membrane. To complete this process, the sperm acrosome reaction plays two major roles: to release acrosomal contents into the extracellular space, which possibly facilitate sperm penetration through the $\mathrm{ZP}$, and to remodel the sperm surface so that it can participate in sperm-oocyte fusion.

We do not currently understand mammalian fertilization at the molecular level. For example, ZP3, which is a component glycoprotein of the oocyte $\mathrm{ZP}$, had been long believed to act as a sperm receptor that triggers the acrosome reaction (Litscher et al. 2009,
Wassarman \& Litscher 2009). However, there are recent data that contradict this interpretation (Baibakov et al. 2007, Dean 2007, Gahlay et al. 2010). As another example, both the sperm immunoglobulin-like protein IZUMO1 (Inoue et al. 2005) and the oocyte tetraspanin protein CD9 (Kaji et al. 2000, Le Naour et al. 2000, Miyado et al. 2000) appear to be required for spermoocyte fusion in mice, yet the fusogenic mechanism including how sperm IZUMO1 and oocyte CD9 are involved is still mysterious.

Currently, there are too many gaps in the available data to allow a comprehensive and coherent model of fertilization in animals. A fundamental problem is that sperm and oocytes are specialized, terminally differentiated cell types that are haploid. Consequently, there are few useful tools, such as RNA-mediated interference using tissue-cultured cells, which can be applied to explore gene functions in vitro. Analysis of genetically manipulated animals is currently the only rigorous way to investigate the functions of fertilization-related genes. 
Indeed, much recent progress in fertilization research has resulted from studies of gene-targeted mice (Inoue et al. 2007, Okabe \& Cummins 2007, Ikawa et al. 2008).

We have recently evaluated the mouse sperm proteome (Stein et al. 2006), in order to identify candidate genes that would be investigated by gene targeting. Among the identified mouse sperm proteins, there was a single-pass transmembrane protein (166 amino acids) encoded by the Tmem190 gene (also known as 4930572D21Rik or UniGene Ms.160043). Tmem190 contains five exons (Fig. 1A, upper) and is a single-copy gene located on the chromosome 7 . This gene is likely testis-specific, since mouse expressed sequence tag (EST) clones of Tmem190 were isolated exclusively from the testis. As for the human ortholog gene TMEM190 (also known as MDAC1 or UniGene Hs.590943), its EST clones were isolated from the pharynx and the ovary. However, it is not yet clear whether TMEM190 is expressed in the human testis.

Mouse and human TMEM190 proteins (68\% identity to each other) possess a single trefoil domain (also called the P-domain or TFF domain) in the extracellular region (Fig. 1A, lower), although the entire sequences of these two proteins show no significant homology to those of other proteins. The trefoil domain consists of six conserved Cys residues that form three disulfide linkages in the pattern of Cys1-Cys5, Cys2-Cys4, and Cys3-Cys6 (Fig. 1A, lower). This domain has been implicated in binding, probably to carbohydrates and/or proteins (Hoffmann \& Hauser 1993, Otto \& Wright 1994, Kjellev 2009). Indeed, the trefoil domain is contained in a variety of proteins that participate in protein-protein and/or protein-carbohydrate interactions, such as sucrase-isomaltase (Alfalah et al. 1999, Spodsberg et al. 2001), the ZP-glycoprotein ZP1 (Conner et al. 2005), the human ZP-glycoprotein ZP4 (Conner et al. 2005), and trefoil factors 1-3 (Hoffmann \& Hauser 1993, Otto \& Wright 1994, Kjellev 2009).

Moreover, small single-pass transmembrane proteins from various species and tissues have been known to associate with self and/or non-self proteins to play roles in regulation of $\mathrm{Na} / \mathrm{K}-\mathrm{ATPase}$ (Rivard et al. 2005), mitochondrial oxidative phosphorylation (Zickermann et al. 2010), ligand-independent activation of receptors (Freeman-Cook \& Dimaio 2005, Lai et al. 2005), polarization of epithelial cells (Makarova et al. 2003,

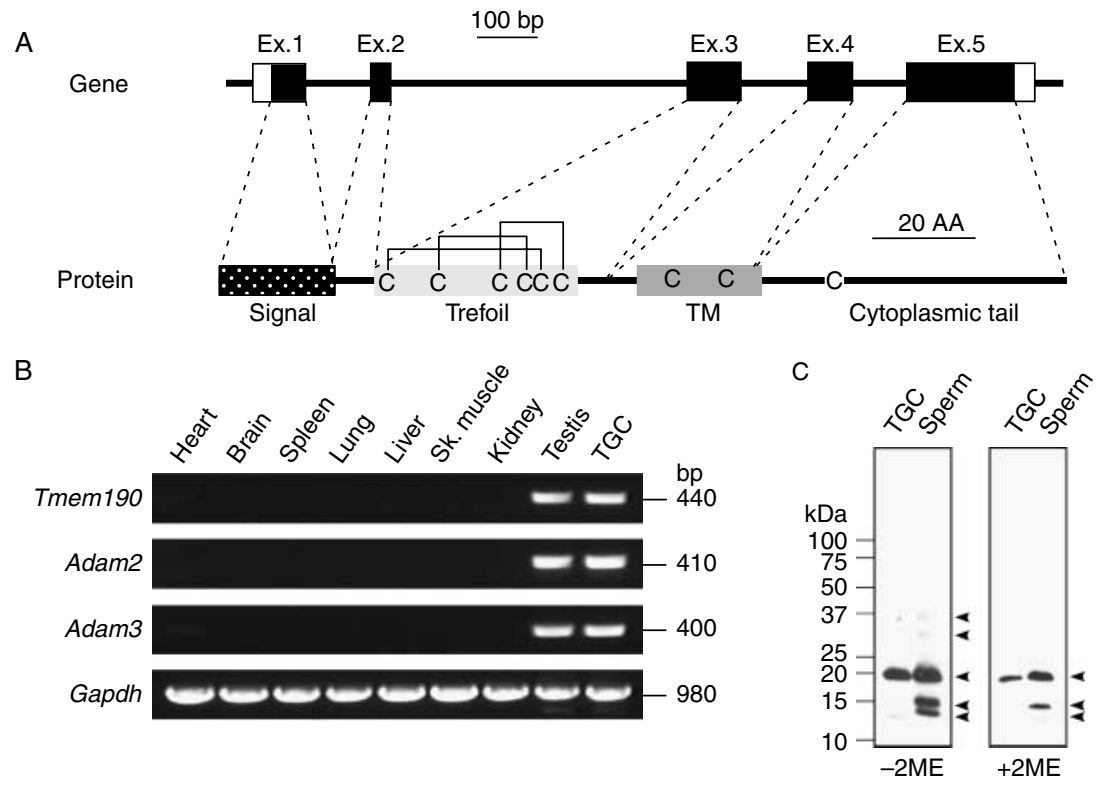

Figure 1 The mouse Tmem190 gene encodes a 19-kDa sperm-specific transmembrane protein containing a single trefoil domain. (A) Structures of the mouse Tmem190 gene and its predicted protein. (Upper) Protein-coding and non-coding regions in each exon (Ex.) are shown by black and white boxes respectively, while intervening horizontal lines represent introns. Broken lines indicate boundaries of the protein regions that each exon encodes. (Lower) Tmem 190 codes for a protein that consists of a signal sequence followed by the trefoil, transmembrane (TM), and cytoplasmic tail domains. The prediction of each domain was based on the Ensemble (http://uswest.ensembl.org) and/or SMART (http://smart.embl-heidelberg.de) databases. In this protein, six out of nine Cys residues (C) are presumed to form three disulfide bonds in the pattern of C1-C5, C2-C4, and C3-C6. AA, amino acid. (B) RT-PCR analysis for the Tmem190 gene. Gene expression of Tmem190 was examined by RT-PCR in various mouse tissues including testis and TGCs. The mouse testis-specific genes Adam2 and Adam3 were also tested as positive controls. RT-PCR for the mouse Gapdh gene, which is ubiquitously expressed, was used as an internal positive control. Calculated sizes of each PCR product are $435 \mathrm{bp}$ (Tmem190), $411 \mathrm{bp}$ (Adam2), $398 \mathrm{bp}$ (Adam3), and $983 \mathrm{bp}$ (Gapdh). The data shown here are representatives of three independent experiments. Sk., skeletal. (C) Immunoblot analysis for TMEM190 protein. Cell lysates of TGCs $\left(0.5 \times 10^{6} \mathrm{TGCs} /\right.$ lane $)$ or cauda epididymal sperm $\left(1 \times 10^{6} \mathrm{sperm} / \mathrm{lane}\right) \mathrm{were}$ separated by $14 \%(\mathrm{w} / \mathrm{v})$ SDS-PAGE in the presence or absence of 2-mercaptoethanol (2ME), followed by immunoblotting using $\alpha$-TMEM190. Arrowheads indicate immunoreactive signals derived from TMEM190, since they were not detected with rblgG (data not shown). Three independent experiments confirmed these data. 
Roh et al. 2003), synthesis of poly-phosphate chains (Fang et al. 2007), and organization of the Golgi apparatus (Rojo et al. 2000).

Based on these lines of evidence, we hypothesized that TMEM190 acts during fertilization by creating a protein complex with itself and/or other mouse sperm proteins. In this study, mouse TMEM190 was characterized by biochemical and cytological approaches, and a mouse line that carries a null-mutated allele of the Tmem190 gene was created. Our data demonstrated that TMEM190 is co-localized with IZUMO1 in mouse sperm before and after the acrosome reaction. TMEM190 was also found to associate with several sperm proteins, but not with IZUMO1. Since male mice lacking TMEM190 were normally fertile, the function(s) of this mouse sperm protein is probably dispensable during fertilization.

\section{Results}

\section{The mouse Tmem190 gene shows testis-specific transcription and encodes a 19-kDa protein found in male germ cells and gametes}

The only EST clones of mouse Tmem 190 were isolated from testis, suggesting that this mouse gene has testisspecific transcription. To confirm this possibility, we examined expression of the Tmem190 gene in various mouse tissues by RT-PCR. As shown in Fig. 1B, a PCR product for Tmem190 was found only in first-strand cDNA samples created from mRNA of mouse testis or testicular germ cells (TGCs, a mixed population of spermatogenic cells at various stages). This pattern of testis-specific expression was also observed for the Adam 2 or Adam 3 genes, but the ubiquitously expressed glyceraldehyde-3-phosphate dehydrogenase gene Gapdh was amplified in all tested samples. These data show that the mouse Tmem190 gene is expressed specifically in the testis.

Next, we investigated expression of the Tmem190encoded protein during spermatogenesis. Protein extracts of TGCs or sperm were examined by immunoblotting using affinity-purified rabbit anti-mouse TMEM190 antibody ( $\alpha$-TMEM190; Fig. 1C). In TGC lysates, a prominent $19-\mathrm{kDa}$ protein was detected with $\alpha$-TMEM190 under the non-reducing and reducing conditions. A $14-\mathrm{kDa}$ immunoreactive signal was detected in non-reduced TGC proteins, but not in reduced samples. These results indicate that TGCs contain TMEM190, which exists mostly as a 19-kDa single-chain protein. The $14-\mathrm{kDa}$ variant is probably a multi-chain form of the TMEM190 protein where two or more chains are linked together by disulfide bonds.

Non-reduced sperm extracts contained 19-, 15-, and $14-\mathrm{kDa}$ proteins that reacted strongly and $37-$ and $32-k$ Da proteins that reacted weakly with $\alpha$-TMEM190. Sperm extracts after reduction lacked the two largest variants but still contained prominent 19-, 15-, and faint 14-kDa proteins. These data suggest that most of the 19- and 15-kDa bands represent single-chain forms, whereas the $14-\mathrm{kDa}$ band corresponds to a multi-chain protein. The 37- and 32-kDa proteins observed under non-reducing conditions are likely to be multimeric forms consisting of some combination of the 19-, 15-, and 14-kDa TMEM190 variants.

\section{TMEM190 mostly resides within TGCs, although this protein is partly present on the cell surface}

To gain clues about the TMEM190 function(s) during fertilization, we determined the localization of this protein in mouse TGCs, acrosome-intact sperm (AIsperm), and acrosome-reacted sperm (AR-sperm). Firstly, TGCs were prepared from the mouse line B6FJS1, in which soluble green fluorescent protein (GFP) accumulates exclusively in the sperm acrosomes (Kim \& Gerton 2003). Therefore, TGCs, which are progenitor cells of sperm, contain GFP as an intracellular protein. Cell suspensions (Fig. 2A, left upper panel) and lysates (Fig. 2A, right upper panel) of TGCs were digested with proteinase $\mathrm{K}$, followed by immunoblotting for the TGCsurface protein SPAM1 (formerly $\mathrm{PH}-20$; Nishimura et al. 2007). This protein almost or completely disappeared in cell suspensions and lysates at any tested concentration of proteinase $\mathrm{K}$, demonstrating that most SPAM1 resides on the TGC surface. On the other hand, both 29- and 27-kDa proteins of GFP, which presumably correspond to precursor and mature forms respectively, were not affected by up to $100 \mu \mathrm{g} / \mathrm{ml}$ proteinase $\mathrm{K}$ in intact TGCs (Fig. 2A, left middle panel). In TGC lysates (Fig. 2A, right middle panel), proteinase $\mathrm{K}$ degraded 29-kDa GFP at all tested concentrations and $27-k D a$ GFP at $20 \mu \mathrm{g} / \mathrm{ml}$ or higher concentrations. These results expectedly show that GFP is intracellularly localized in TGCs.

By treatment of intact TGCs with $10-100 \mu \mathrm{g} / \mathrm{ml}$ proteinase $\mathrm{K}$, small but significant amounts of $19-\mathrm{kDa}$ TMEM190 were degraded into a 15-kDa protein (Fig. 2A, left lower panel). As lysed TGCs were used (Fig. 2A, right lower panel), the 19-kDa immunoreactive signal was completely missing even at the lowest concentration $(10 \mu \mathrm{g} / \mathrm{ml})$ of proteinase $\mathrm{K}$, and the $15-\mathrm{kDa}$ signal was mostly erased by the addition of $100 \mu \mathrm{g} / \mathrm{ml}$ proteinase $\mathrm{K}$. Therefore, testicular TMEM190 seems to be an intracellular protein, although a small fraction of this protein is present on the cell surface.

We also examined the TMEM190 localization in mouse TGCs by immunofluorescence (Fig. 2B). Methanol-fixed TGCs were treated with mock or $0.1 \%(\mathrm{v} / \mathrm{v})$ Triton X-100 (TX100) for permeabilization, followed by staining with $\alpha$-TMEM190. To monitor the acrosome formation during spermatogenesis, we counter-stained the same TGCs with peanut agglutinin (PNA), which is a probe to detect the sperm acrosomes. Among mock-permeabilized TGCs, 
A

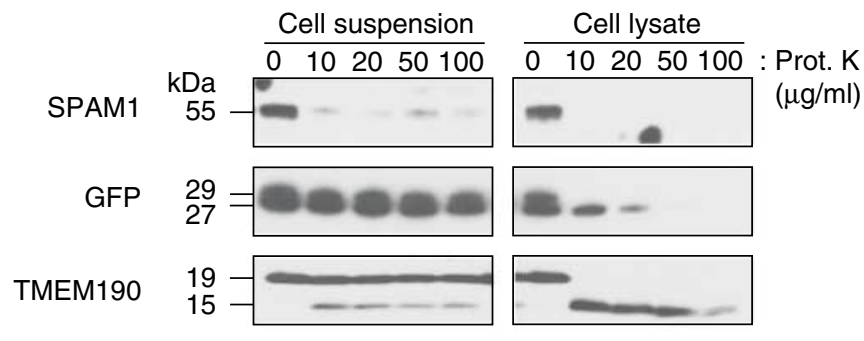

B

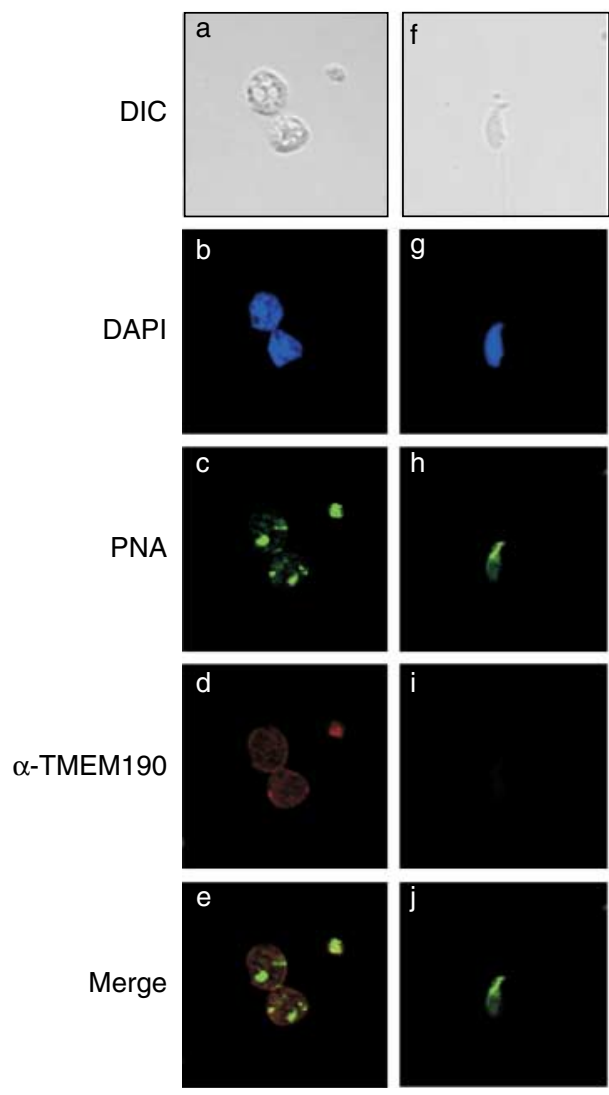

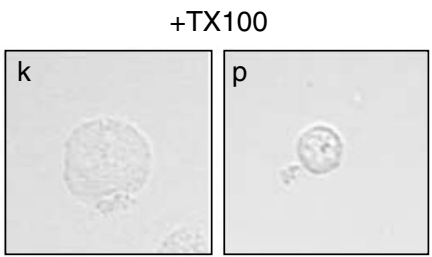
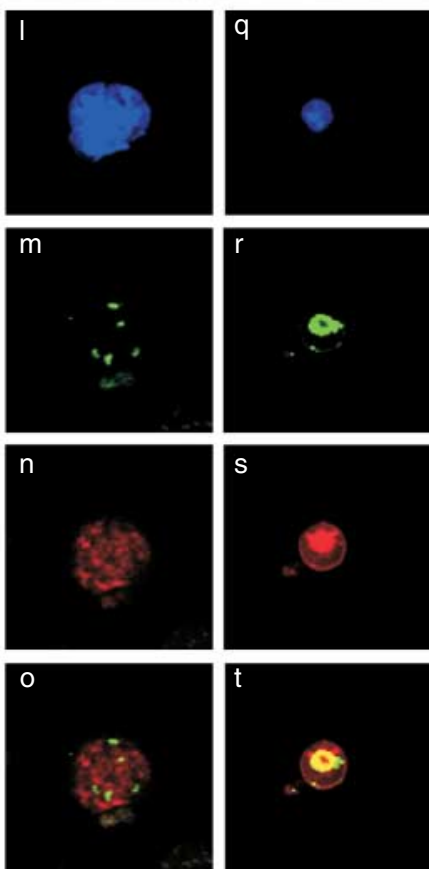

Figure 2 Testicular TMEM190 is mostly an intracellular protein. (A) Proteinase $\mathrm{K}$ digestion of TGC-surface proteins. TGCs were isolated from the transgenic mouse line B6SJF1, in which GFP is present within the sperm acrosomes. Therefore, GFP is intracellularly present in TGCs. Cell suspensions and lysates were prepared from the GFP-carrying TGCs, digested with various concentrations of proteinase $\mathrm{K}$, and analyzed by immunoblotting $\left(0.5 \times 10^{6} \mathrm{TGCs} /\right.$ lane $)$ for SPAM1, GFP, or TMEM190. SPAM1 and GFP were examined as positive controls for TGC-surface and intracellular proteins respectively. This result was confirmed by three independent experiments. Prot. K, proteinase K. (B) Immunofluorescence of mouse TGCs for TMEM190. After methanolfixed TGCs of CD1 mice were treated with mock ( - TX100) or TX100 (+ TX100) for permeabilization, these TGC samples were incubated with rblgG or $\alpha$-TMEM190. The same cells were counter-stained with DAPI for nuclei and PNA for monitoring the acrosome formation. We did not detect any significant immunoreactive signal with rblgG (data not shown). Three independent experiments confirmed the data shown here. DIC, differential interference contrast. round spermatids contained TMEM190 on the cell surface (Fig. 2Bd and Be), whereas this protein was barely found on the testicular sperm surface (Fig. 2Bi and $\mathrm{Bj}$ ). As TGCs were permeabilized with TX100, immunoreactive signals of TMEM190 were unevenly distributed within the intracellular space of primary spermatocytes (Fig. 2Bn and Bo). In round spermatids, TMEM190 was localized both on the cell surface and in the ring-shaped organelle, which probably corresponds to an intermediate structure of the acrosome whose formation processes during spermatogenesis (Fig. $2 \mathrm{Br}$ and $\mathrm{Bt}$ ). We carried out similar experiments using normal rabbit lgG (rblgG) instead of $\alpha$-TMEM190, but no significant immunoreactive signal was detected in any tested sample (data not shown).

These findings indicate that primary spermatocytes pre-meiotically contain intracellular TMEM190 protein.
It was also shown that, in post-meiotic round spermatids, TMEM190 resides mostly in the intracellular space and partly on the cell surface, whereas the surface of testicular sperm barely contains TMEM190. Moreover, these immunofluorescence-based data (Fig. 2B) were in good agreement with the results obtained by the proteinase $\mathrm{K}$ digestion assay of TGCs (Fig. 2A).

\section{TMEM190 relocates from the inner-acrosomal membrane onto the equatorial segment surface during the acrosome reaction}

We next determined the localization of mouse TMEM190 in Al- and AR-sperm. For the proteinase $\mathrm{K}$ digestion assay, Al-sperm (cauda epididymal sperm) were prepared from B6FJS1 mice. Intact (Fig. 3A, left upper panel) and lysed (Fig. 3A, right upper panel) 
A

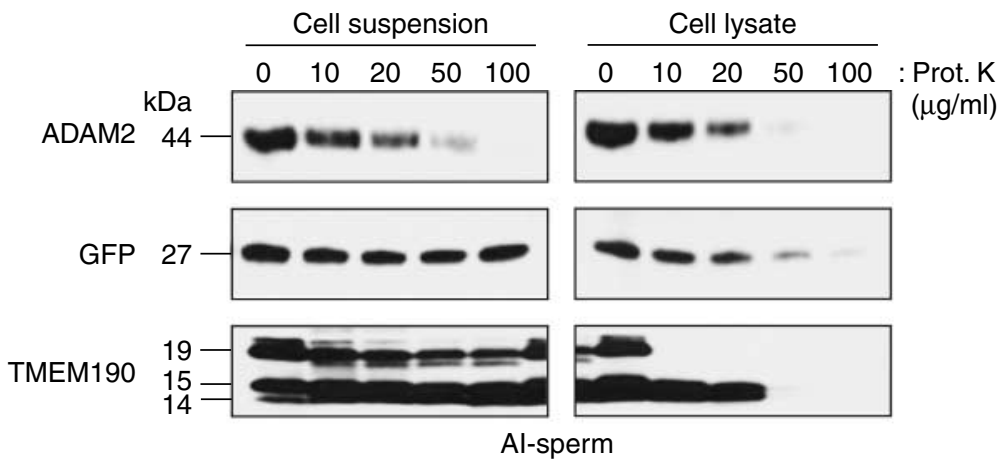

B

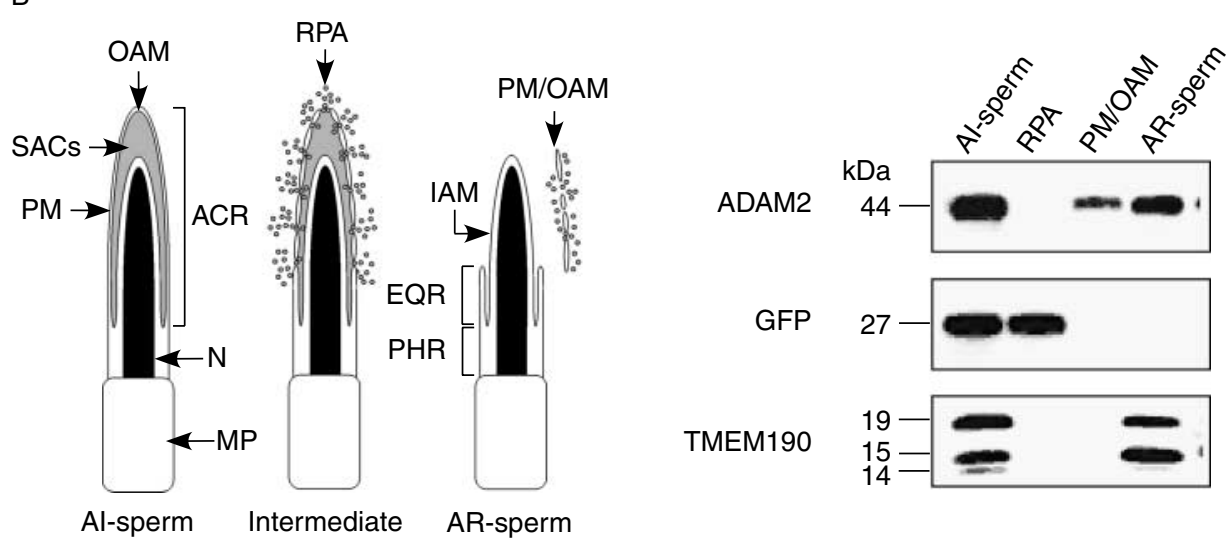

Figure 3 TMEM190 is present in the intracellular head region of mature sperm. (A) Proteinase K digestion of sperm-surface proteins. Cauda epididymal sperm carrying acrosomal GFP were isolated from B6SJF1 mice. Cell suspensions and lysates were prepared from the sperm, digested with various concentrations of proteinase $K$, and analyzed by immunoblotting $\left(1 \times 10^{6}\right.$ sperm/lane $)$ for ADAM2, GFP, or TMEM190. ADAM2 and GFP were examined as positive controls for sperm-surface and intracellular proteins respectively. This result was confirmed by three independent experiments. Prot. K, proteinase K. (B) Subcellular localization of TMEM190 in mouse sperm. (Left) Subcellular fractionation of mouse sperm that were subjected to the A23187-induced acrosome reaction. OAM, outer-acrosomal membrane; PM, plasma membrane; SACs, soluble acrosomal contents; ACR, acrosomal cap region; N, nucleus; MP, midpiece; IAM, inner-acrosomal membrane; EQR, equatorial region; and PHR, posterior head region. (Right) Immunoblotting of subcellular components for TMEM190. Proteins contained in each subcellular fraction (equivalent to $1 \times 10^{6}$ sperm/lane) were separated by $14 \%(\mathrm{w} / \mathrm{v})$ SDS-PAGE and then analyzed by immunoblotting for ADAM2, GFP, or TMEM190. ADAM2 and GFP represent typical cell-surface and soluble acrosomal proteins respectively, and they served as controls. These data are representatives of three independent experiments.

Al-sperm were treated with proteinase $\mathrm{K}$ and then analyzed by immunoblotting for the sperm-surface protein ADAM2 (Kim et al. 2003, 2004). The amounts of this protein were reduced as a function of the proteinase $\mathrm{K}$ concentration, and similar proteolytic rates were observed irrespective of whether or not the $\mathrm{Al}$-sperm were lysed prior to proteinase $\mathrm{K}$ addition; as expected, our results confirmed that ADAM2 is a spermsurface protein. In contrast, intracellular GFP was not obviously affected by up to $100 \mu \mathrm{g} / \mathrm{ml}$ proteinase $\mathrm{K}$ (Fig. 3A, left middle panel), but definite proteolysis of GFP was observed in $\mathrm{Al}$-sperm lysates at either 50 or $100 \mu \mathrm{g} / \mathrm{ml}$ proteinase $\mathrm{K}$ (Fig. 3A, right middle panel).

The 19-, 15-, and 14-kDa TMEM190-derived immunoreactive signals were detected in intact sperm at all tested concentrations of proteinase $\mathrm{K}$ (Fig. 3A, left lower panel). However, in sperm lysates, proteinase $\mathrm{K}$ digested the 19-kDa TMEM190 at any tested concentration and the 15- and 14-kDa proteins at
50 or $100 \mu \mathrm{g} / \mathrm{ml}$ (Fig. 3A, right lower panel). These data indicate that most TMEM190 is intracellular in Al-sperm. However, TMEM190 might be partly located on the surface of intact sperm, since 19-kDa TMEM190 seemed to be slightly degraded into a $15-$ or a $14-\mathrm{kDa}$ protein by increasing the proteinase $\mathrm{K}$ concentration (Fig. 3A, left lower panel).

We also determined the subcellular fraction(s) of mouse sperm that contained TMEM190 (Fig. 3B). Cauda epididymal sperm were prepared from B6FJS1 mice, incubated with the calcium ionophore A23187 to induce the acrosome reaction, and fractionated into subcellular components (Fig. 3B, left). We prepared two fractions that were analyzed by immunoblotting (Fig. 3B, right): the soluble acrosomal contents plus the membrane proteins released during the acrosome reaction (RPA fraction) and mixed vesicles of the plasma and outer-acrosomal membranes (PM/OAM fraction). As previously reported (Kim et al. 2003, 2004), ADAM2 


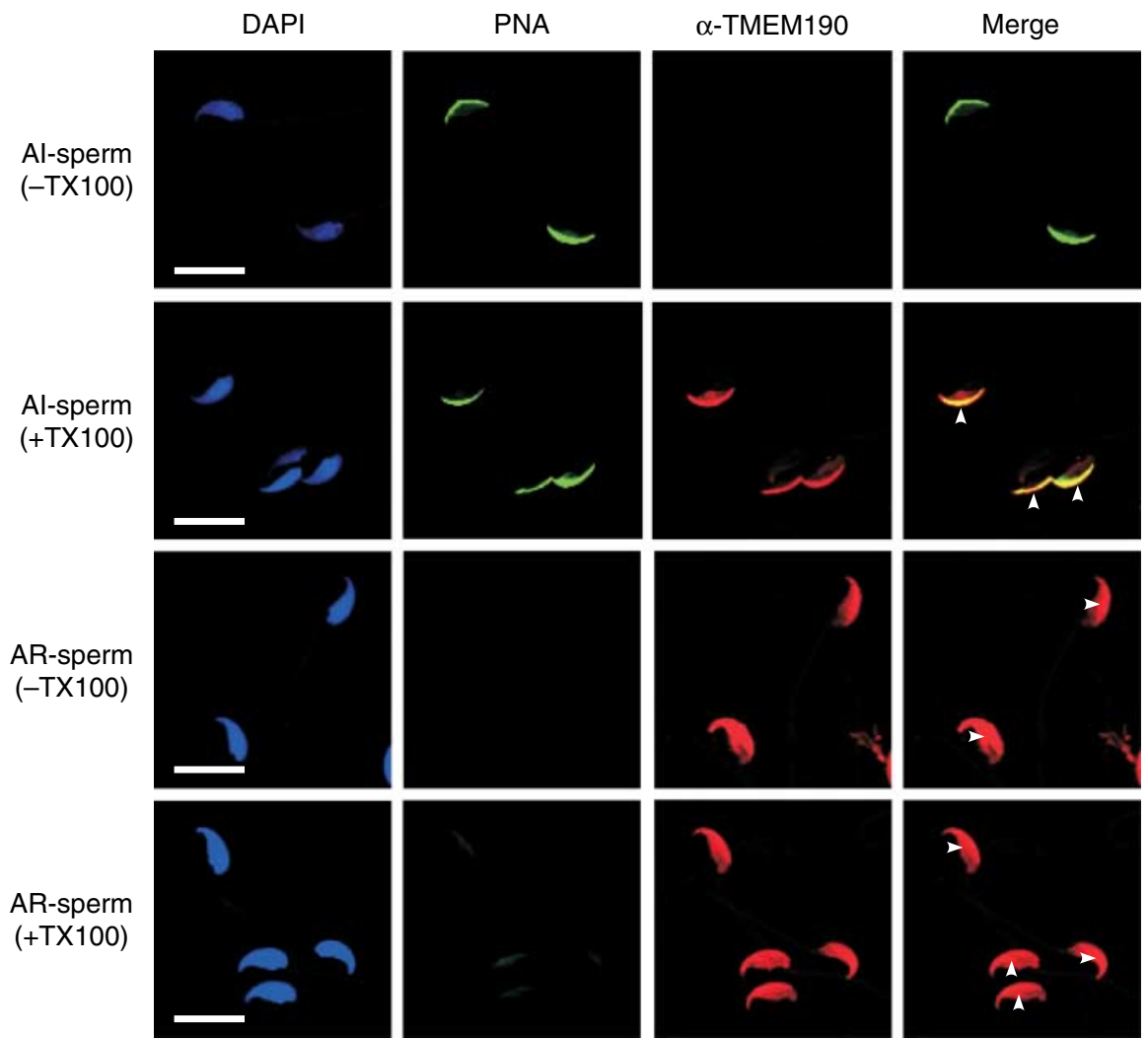

Figure 4 Intracellular TMEM190 protein partly relocates onto the equatorial segment surface of mouse sperm during the A23187-induced acrosome reaction. After $\mathrm{Al}$ - or AR-sperm of CD1 mice were treated with mock (-TX100) or TX100 (+TX100) for permeabilization, these sperm samples were incubated with rblgG or $\alpha$-TMEM190. The same cells were counter-stained with DAPI and PNA for nuclei and acrosomes respectively. White arrowheads show the localization of TMEM190 in Al- or AR-sperm. No obvious signal was detectable with rblgG (data not shown). Three independent experiments confirmed the data shown here. Bar $=10 \mu \mathrm{m}$. was found in PM/OAM fraction and unfractionated AR-sperm (Fig. 3B, right upper panel). GFP, a marker protein of the sperm acrosome, was exclusively present in RPA fraction after the acrosome reaction (Fig. 3B, right middle panel). Therefore, previously characterized subcellular components of mouse sperm were fractionated in the expected manner. We found that the TMEM190 protein is present in AI- and AR-sperm, but not in RPA and PM/OAM fractions (Fig. 3B, right lower panel). Furthermore, TMEM190 was contained in the acrosome-reacted sperm head (ARH) fraction (data not shown). These results show that most TMEM190 stays at the sperm heads even after the acrosome reaction.

Immunofluorescence was then conducted to further examine the subcellular location of TMEM190 in mouse sperm (Fig. 4). In mock-permeabilized Al-sperm, any significant immunoreactive signal was not detected with rblgG (data not shown) or $\alpha$-TMEM190. However, Al-sperm permeabilized with $0.1 \%(\mathrm{v} / \mathrm{v})$ TX100 showed an immunoreactive signal with $\alpha$-TMEM190, but not with rblgG (data not shown), around the rim of the acrosomes. These data indicate that TMEM190 is mostly localized in the inner-acrosomal membrane of $\mathrm{Al}$-sperm. In contrast, regardless of whether or not AR-sperm were permeabilized, TMEM190 seemed to partly relocate during the acrosome reaction from the inner-acrosomal membrane onto the equatorial segment surface. Interestingly, this relocation pattern was similar to that of mouse IZUMO1 (Kawai et al. 1989, Yamashita et al. 2007, Fujihara et al. 2010), an essential protein for sperm-oocyte fusion (Inoue et al. 2005).

\section{TMEM190 is co-localized with IZUMO1 in mouse sperm before and after the acrosome reaction}

To our knowledge, IZUMO1 is the only protein to satisfy both of that it resides in sperm similarly to TMEM190 and that its role during fertilization is clear. Therefore, we examined whether TMEM190 and IZUMO1 are co-localized together in permeabilized AI- or AR-sperm (Fig. 5), to access the TMEM190 function(s). TMEM190 was found to co-localize with IZUMO1 at the inneracrosomal membrane of Al-sperm. In AR-sperm, both TMEM190 and IZUMO1 were present at the inneracrosomal membrane and partly at the equatorial segment. These data demonstrate that TMEM190 and IZUMO1 co-localize in mouse sperm both before and after the acrosome reaction.

\section{TMEM190 forms a protein complex(es) with other sperm proteins, but not with IZUMO1}

We immunoprecipitated TMEM190 to investigate whether this protein associates with IZUMO1 (Fig. 6A). In all tested cell lysates (total), immunoprecipitates with neither rblgG- nor $\alpha$-TMEM190-beads included 


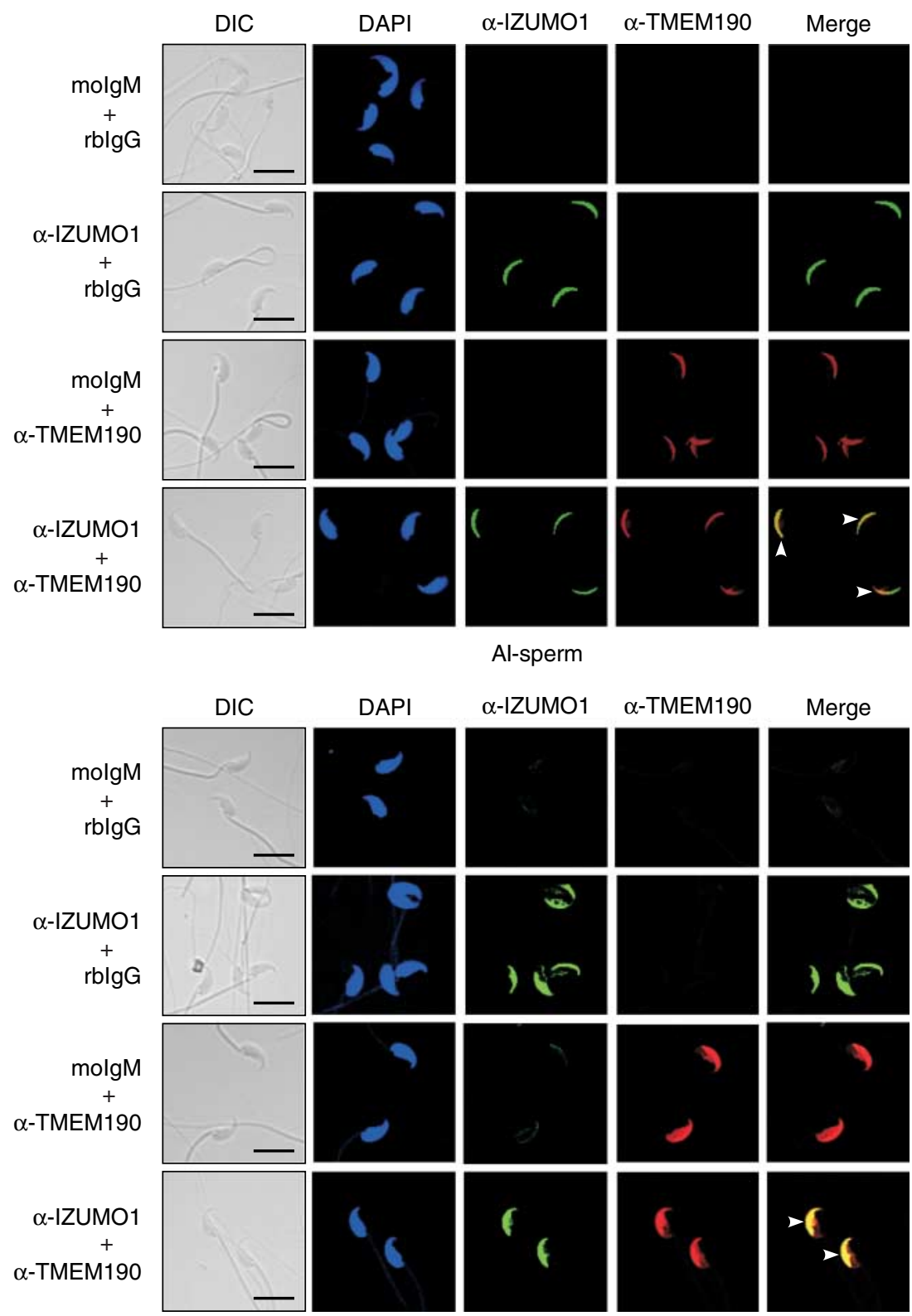

Figure 5 Mouse sperm TMEM190 is co-localized with IZUMO1. TX100-permeabilized Al- or AR-sperm were stained with molgM or $\alpha$-IZUMO1 and rblgG or $\alpha$-TMEM190. All sperm samples were also stained with DAPI to visualize each nucleus. White arrowheads indicate that IZUMO1 and TMEM190 are co-localized together in Al- or AR-sperm. These data are representatives of three independent experiments. DIC, differential interference contrast. Bar $=10 \mu \mathrm{m}$.
IZUMO1 (Fig. 6A, left panel), whereas TMEM190 clearly formed an immune complex specifically with $\alpha$-TMEM190 (Fig. 6A, right panel). These data reveal that TMEM190 is physically independent of IZUMO1 in mouse TGCs, Al-sperm, and AR-sperm under immunoprecipitating conditions. However, it remains possible that TMEM190 and IZUMO1 are loosely associated and do not withstand the methods used for immunoprecipitation.

We also explored the possibility that TMEM190 associates with other sperm proteins (Fig. 6B). Cellsurface proteins on AR-sperm were biotinylated, bound to monomeric avidin-beads, washed, and eluted to prepare a fraction containing sperm-surface proteins (surface). To check whether biotinylation is restricted to cell-surface proteins, 'total' and 'surface' fractions of AR-sperm before or after biotinylation were examined by immunoblotting for the sperm-surface protein ADAM2 (Fig. 6B, left upper panel) or the intracellular protein $\alpha$-tubulin (Fig. 6B, left lower panel). ADAM2 exhibited a slower migration in biotinylated 'total' fractions than control samples, indicating that ADAM2 was modified with biotin. Indeed, this protein was found in 'surface' fractions of biotinylated, but not mock-biotinylated, AR-sperm. On the other hand, $\alpha$-tubulin was indistinguishable in size between mock- and actually biotinylated 'total' samples. Moreover, 'surface' samples of biotinylated AR-sperm did not contain this protein. 


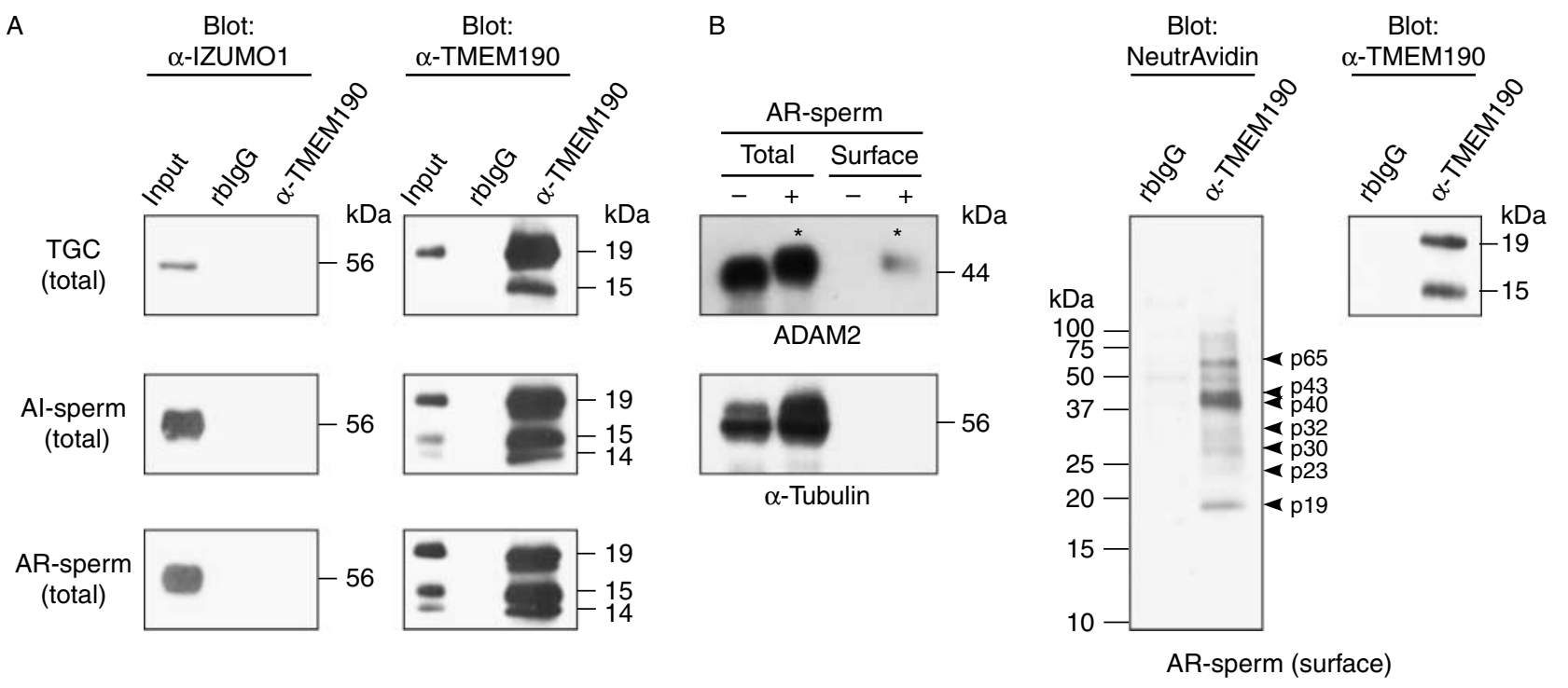

Figure 6 TMEM190 is not directly associated with IZUMO1 but forms a complex(es) with other sperm proteins. (A) Complex formation of TMEM190 with IZUMO1. For immunoprecipitation, protein extracts (total) of TGCs, Al-sperm, or AR-sperm were incubated with rblgG- or $\alpha$-TMEM190immobilized Sepharose beads. The precipitated protein fractions $\left(0.5 \times 10^{7} \mathrm{TGCs} /\right.$ lane or $\left.1 \times 10^{7} \mathrm{sperm} / \mathrm{lane}\right)$ and 'total' samples prior to immunoprecipitation (input, $0.5 \times 10^{6} \mathrm{TGCs} / \mathrm{lane}$ or $1 \times 10^{6}$ sperm/lane) were then examined by immunoblot analysis using $\alpha$-IZUMO1 or $\alpha$-TMEM190. We confirmed this result by three independent experiments. (B) Complex formation of TMEM190 with other sperm proteins. (Left) Surface protein fractions (surface) were prepared from biotinylated AR-sperm. To confirm that cell-surface proteins, but not intracellular proteins, were biotinylated, 'total' and 'surface' fractions (equivalent to $1 \times 10^{6} \mathrm{sperm} / \mathrm{lane}$ ) of non-biotinylated ( - ) or biotinylated (+) AR-sperm were analyzed by immunoblotting for ADAM2 (cell-surface protein) or $\alpha$-tubulin (intracellular protein). Asterisks show that ADAM2 is size-shifted due to modification with biotin. (Right) 'Surface' fractions of AR-sperm were immunoprecipitated with rblgG- or $\alpha$-TMEM190-beads. The precipitated biotinylated proteins (equivalent to $1 \times 10^{7}$ sperm/lane) were analyzed by blotting using NeutrAvidin or $\alpha$-TMEM190 as probes. Molecular sizes $(\mathrm{kDa})$ of the co-precipitated proteins are expressed as ' $\mathrm{p}+$ number' (for example, p65 represents a 65-kDa protein). The data shown here are representatives of three independent experiments.

Therefore, 'surface' fractions of AR-sperm were appropriately prepared.

TMEM190 was then immunoprecipitated with $\alpha$-TMEM190-beads in 'surface' fractions. After coprecipitated proteins were separated by SDS-PAGE, they were transferred onto membranes and captured by incubation of the blotted membranes with NeutrAvidin (Fig. 6B, middle panel) or $\alpha$-TMEM190 (Fig. 6B, right panel). TMEM190 and its co-precipitated proteins were contained only in the immunoprecipitates with $\alpha$-TMEM190-beads. Particularly, 65-, 43-, 40-, and $19-\mathrm{kDa}$ proteins showed clear association with TMEM190. It is not yet clear whether the biotinylated 19-kDa protein is TMEM190, since a 15-kDa surface protein was not found in the immune complexes including both 19- and 15-kDa TMEM190. Efficiency of biotinylation might be different between these two TMEM190-derived proteins. At any rate, these combined results demonstrate that TMEM190 forms a protein complex(es) on the AR-sperm surface with, at least, 65-, 43-, and 40-kDa proteins.

\section{Tmem190-null mice are fertile}

Finally, we created mice lacking TMEM190 to elucidate the in vivo function(s) of this protein. The entire region of the Tmem190 gene was replaced by the neomycinresistance gene cassette in the mouse genome by homologous recombination (Fig. 7A). This gene targeting was confirmed by PCR genotyping of tail DNA samples that had been prepared from $T_{m e m} 190^{+/+}$, Tmem $190^{+/-}$, or Tmem $190^{-/-}$mice (Fig. 7B). Moreover, TMEM190 protein was completely missing in TGCs and cauda epididymal sperm of Tmem190-null mice, whereas IZUMO1, a co-localized protein with TMEM190, was of normal amounts in the same TGC or sperm samples (Fig. 7C). Protein levels of ADAM2, ADAM3, and SPAM1, of which functions are presumably independent of the TMEM190 function(s), were similar between Tmem $190^{+/+}$and Tmem $190^{-1-}$ cell lysates of TGCs or cauda epididymal sperm (data not shown). These data show that a mouse line lacking TMEM190 was established.

By crossing of Tmem $190^{+/-}$male and female mice, Tmem $190^{-}-$mice were produced according to the expected Mendelian frequency $\left(\right.$ Tmem $_{190^{+/+}}$: Tmem 190 ${ }^{+/-}:$Tmem $190^{-1-}=32 \quad(24 \%): 68 \quad(50 \%): 36$ $(26 \%))$, and a ratio of Tmem $190^{-1-}$ male and female progeny was also as expected (male:female $=17$ $(47 \%): 19(53 \%))$. There was no significant abnormality affecting the health, body size, and behavior in Tmem $190^{-1-}$ mice. 
A
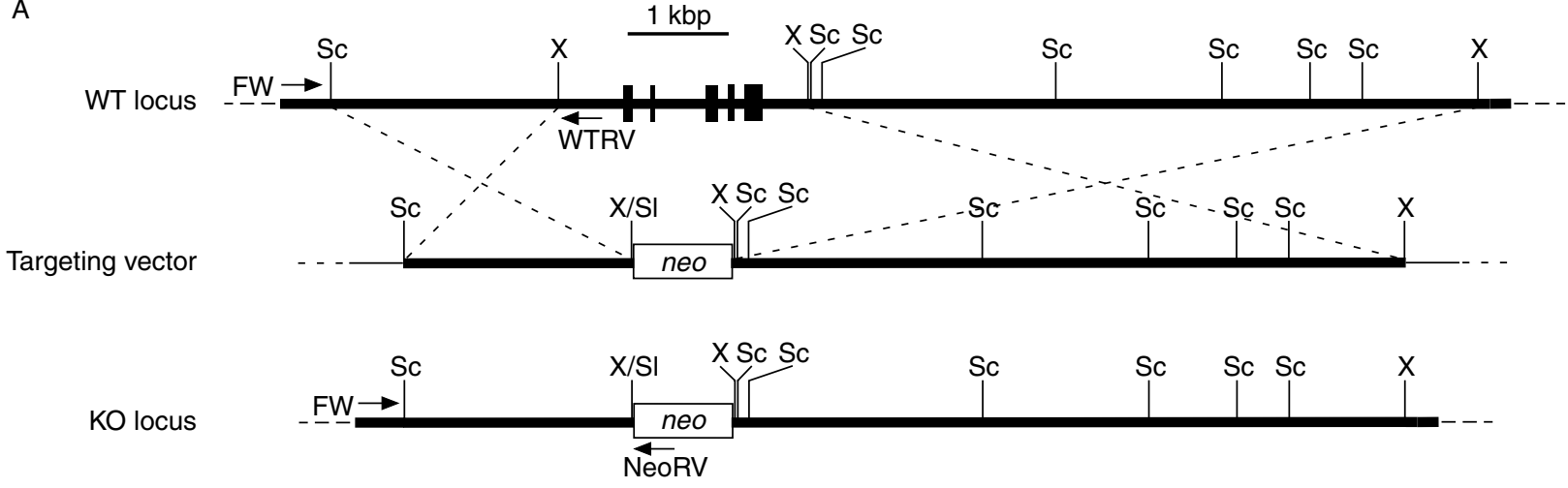

B

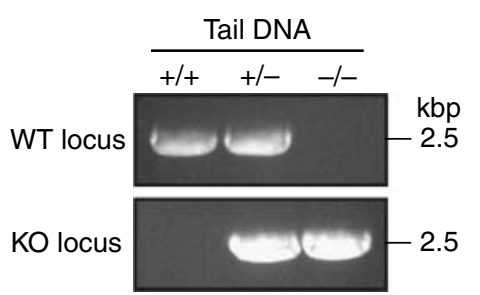

C

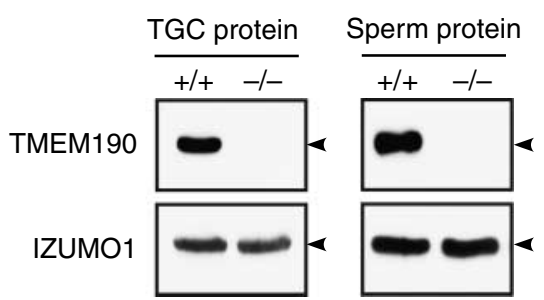

D

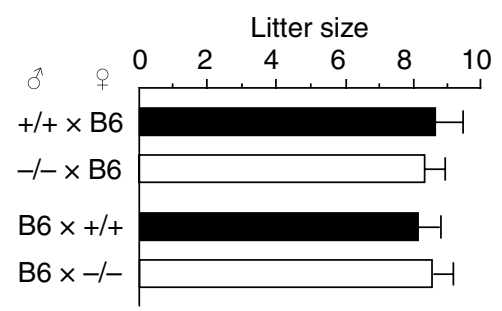

Figure 7 Tmem190-null mice are fertile. (A) The targeting strategy used for the mouse Tmem190 gene. Exons and introns of Tmem190 are shown by black boxes and intervening horizontal lines respectively. White boxes represent the neomycin-resistance gene (neo) cassette. A targeting vector was linearized at the Kpnl site (not shown) before electroporation into mouse ES cells. FW, WTRV, and NeoRV were PCR primers used for genotyping of ES cell clones or mouse tails. WT, wild-type; KO, knock-out; Sc, Sacl; X, Xhol; and SI, Sall. (B) PCR genotyping of mice carrying the targeted

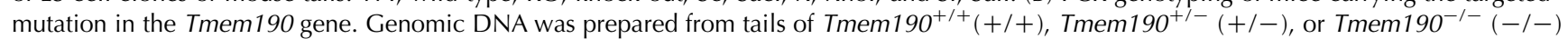
mice and used for PCR genotyping. This result is a representative of three independent experiments. (C) Immunoblotting of Tmem190-null TGCs and sperm. Protein extracts were prepared from TGCs or cauda epididymal sperm of Tmem $190^{+/+}(+/+)$or $\operatorname{Tmem}^{190^{-/-}}(-/-)$mice and then analyzed by immunoblotting $\left(0.5 \times 10^{6} \mathrm{TGCs} /\right.$ lane and $\left.1 \times 10^{6} \mathrm{sperm} / \mathrm{lane}\right)$. Arrowheads indicate immunoreactive signals for $19-\mathrm{kDa}$ TMEM 190 or 56-kDa IZUMO1. These data were confirmed by three independent experiments. (D) In vivo fertility test of Tmem190-null mice. Tmem190 ${ }^{+/+}$ $(+/+)$ or Tmem $190^{-/-}(-/-)$male mice were individually placed with two C57BL/6 (B6) female mice in a cage. Each female that had a vaginal plug was transferred into a new cage, and the numbers of pups born were counted. The same experiments were also conducted in mating pairs of B6 males and $+/+$ or $-/-$ females. Data are expressed as 'mean \pm s.D.'.

Figure 7D showed the data on in vivo fertility of Tmem190-null mice. As male mice lacking TMEM190 were crossed to $\mathrm{C} 57 \mathrm{BL} / 6$ female mice, an average litter size (mean \pm s.D.) of the males $(8.7 \pm 0.90, n=6)$ was similar to that of Tmem $190^{+/+}$males $(8.5 \pm 0.65, n=7)$. Breeding of $\mathrm{C} 57 \mathrm{BL} / 6$ males and tested females resulted in similar average litter sizes between $\operatorname{Tmem} 190^{+/+}$and Tmem $190^{-1-}$ females $(8.0 \pm 0.65, n=6$ vs $8.5 \pm 0.71$, $n=6)$. Hence, the mouse Tmem 190 gene is not essential for in vivo fertilization.

\section{Discussion}

We previously identified TMEM190 in the mouse sperm proteome as a small transmembrane protein containing the trefoil domain (Stein et al. 2006). From two keywords, 'trefoil domain' and 'small transmembrane protein', we hypothesized that TMEM190 acts during fertilization through the association with self and/or nonself proteins. We found in this study that mouse TMEM190 resides at the inner-acrosomal membrane of $\mathrm{Al}$-sperm and relocates onto the plasma membrane of the equatorial segment during the acrosome reaction. We also found that mouse sperm contain a protein complex(es) including TMEM190. Lastly, mice lacking TMEM190 were normally fertile.

We observed 19-, 15-, and 14-kDa proteins in both non-reduced and reduced sperm extracts by immunoblotting using $\alpha$-TMEM190. Therefore, the 19-kDa protein probably corresponds to intact sperm TMEM190 and is degraded into the 15- or the $14-\mathrm{kDa}$ proteins. A calculated size (16 $476 \mathrm{kDa})$ of the predicted TMEM190 polypeptide lacking a 21-mer signal sequence suggests that the 19-kDa TMEM190 possesses a post-translational modification(s). $\mathrm{N}$-glycans might be the case, because of the $\mathrm{Asn}^{53}$ - Leu ${ }^{54}$-Cys ${ }^{55}$ sequence in the extracellular region of TMEM190. An atypical Asn-XCys sequence has been demonstrated to act as an attachment site for $\mathrm{N}$-glycosylation in a variety of proteins, such as human protein C (Gil et al. 2009), epidermal growth factor receptor (Sato et al. 2000), and CD69 (Vance et al. 1999). Another possible modification is phosphorylation, since the cytoplasmic tail of TMEM190 contains seven Ser (residues 124, 129, 131, 
136, 140, 146, and 158) and one Thr (residue 162) residues, which are potential substrates for protein kinases (http://www.cbs.dtu.dk/services/NetPhos/). On the other hand, most TMEM190 is intracellular in Al-sperm so that we cannot exclude the possibility that the 19-kDa TMEM190 variant corresponds to the predicted full-length polypeptide (calculated size: $18491 \mathrm{kDa})$.

Currently, the biological significance of the 15- and 14-kDa TMEM190 remains elusive. Even when we used sperm lysates that had been treated with various protease inhibitors during preparation (data not shown), 19-, 15-, and $14-k D a$ proteins were detected with $\alpha$-TMEM190 in both non-reduced and reduced samples. Moreover, ratios of these TMEM190-derived proteins showed the batch-to-batch variation, regardless of whether or not sperm proteins were extracted in the presence of protease inhibitors. The degradation of the 19-kDa TMEM190 might occur during the sperm lysate preparation due to unknown sperm protease(s) resistant to our protease inhibitor treatment.

As we determined the TMEM190 localization in mouse TGCs by immunofluorescence, this protein was present partly on the surface of round spermatids that were contained in TGC samples (Fig. 2Bd and Bs). However, testicular sperm, which are a spermatogenic cell population at the later spermatogenesis stage than round spermatids, contained no TMEM190 protein on the surface (Fig. 2Bi). Moreover, by immunofluorescence of mock-permeabilized Al-sperm, we did not obtain evidence for the surface localization of TMEM190 (Fig. 4). It is yet unclear whether TMEM190 is partly localized on the surface of testicular and Al-sperm. Surface TMEM190 on round spermatids, whose ratio to total TMEM190 is low (Fig. 2Bs), might be distributed onto the whole surface of the testicular sperm heads during spermatogenesis, so that immunoreactive signals of the surface TMEM190 would be too diffused to be detected. As another possibility, the surface form of testicular TMEM190 might be proteolytically degraded at later spermatogenesis stage(s), since TMEM190 seems to be highly susceptible to protease digestion as discussed above.

Certain aspects of TMEM190 biology imply that it might be involved in fertilization. One highly suggestive clue is that TMEM190 co-localizes with IZUMO1 (Kawai et al. 1989, Yamashita et al. 2007, Fujihara et al. 2010), which is an essential protein for sperm-oocyte fusion (Inoue et al. 2005). The relocation of both TMEM190 and IZUMO1 during the acrosome reaction is intriguing, since the final destination of these two proteins is the equatorial segment, where the gamete fusion occurs (Yanagimachi 1994). Indeed, when either of the testisspecific serine kinase 6 gene Tssk6 (Sosnik et al. 2009) or the sperm equatorial segment protein 1 gene Spesp1 (Fujihara et al. 2010) is disrupted in mice, their mutant sperm are defective in both the relocation of IZUMO1 and sperm-oocyte fusion. Since we were not able to show that TMEM190 and IZUMO1 interact with each other and Tmem190-null mice are fertile, the fusogenic role(s) of TMEM190, if any, is probably indirect and dispensable.

The second clue is a recent study on sperm CD9 (Ito et al. 2010); this protein also exhibits essentially the same subcellular localization pattern in mouse sperm as those of TMEM190 and IZUMO1. While oocytes from mice lacking CD9 are incapable of being fused with wild-type sperm, CD9-deficient sperm are normal in all tested sperm functions that include the ability to fertilize oocytes (Kaji et al. 2000, Le Naour et al. 2000, Miyado et al. 2000). This shows that the function(s) of mouse sperm CD9 is dispensable during fertilization, like mouse sperm TMEM190 (Fig. 7D). Therefore, CD9 might be functionally related to TMEM190 in mouse sperm with both indirectly regulating sperm-oocyte fusion.

There are two facts about TMEM190 that are puzzling. First, the human TMEM190 gene seems to be expressed predominantly in the pharynx and the ovary unlike the testis-specific expression of the mouse Tmem190 gene. One currently unexplored possibility is that the human gene might be expressed in the testis at low but enough levels to produce the functional TMEM190 protein. If human sperm do not contain TMEM190, another protein(s) might play the same role(s) as that of mouse TMEM190. This possibility is based on the following findings: the mouse testis-specific genes Adam1a (Nishimura et al. 2004) and Adam3 (Shamsadin et al. 1999, Nishimura et al. 2001) are essentially required for male fertility, even though these two genes are both pseudogenes in the human genome (Jury et al. 1997, Grzmil et al. 2001). Currently, there is no follow-up evidence yet in this case, but other human testis/spermspecific ADAM proteins presumably compensate for the functions of mouse ADAM1a and ADAM3.

Second, Tmem190-null mice show normal fertility. Tmem190 might be a mouse gene that requires a two or more multiple-gene knockout within the same animal to cause a profound defect(s) (Shastry 1995). Mouse TMEM190 is found in a multi-protein complex(es) and perhaps if one or more of other components for the sperm protein complex(es) are targeted, the mutant males would be sterile or subfertile.

As a summary, we propose an indirect role(s) of mouse TMEM190 in gamete fusion by comprising a sperm protein complex(es). Alternatively, the protein complex(es) is possibly involved in regulation of the acrosome reaction, since the protein dynamics of TMEM190 is clearly linked to the acrosome reaction. At any rate, the TMEM190 role(s) within the mouse sperm protein complex(es) requires to be examined further. Particularly, TMEM190 and CD9 should be investigated to determine whether they are functionally linked to each other in mouse sperm. It would also 
be worthwhile to clarify whether human sperm contain a protein complex(es) that is functionally equivalent to the TMEM190-bearing mouse sperm protein complex(es). This would lead to understanding the molecular basis of human male infertility.

\section{Materials and Methods}

\section{Animals}

CD1 and C57BL/6 mice were purchased from Charles River Laboratories International, Inc. (Wilmington, MA, USA) and the Jackson Laboratory (Bar Harbor, ME, USA) respectively. The transgenic mouse line B6SJF1 (Kim \& Gerton 2003), in which GFP is localized in the sperm acrosomes, was a kind gift from Dr G L Gerton (University of Pennsylvania, Philadelphia, PA, USA). Tmem190-null mice were created in this study (for details, see 'Creation of Tmem190-null mice'). All these mouse lines were maintained in an animal facility at the University of California Davis (UCD). Rabbits used for immunization to raise $\alpha$-TMEM190 were maintained in the UCD Comparative Pathology Laboratory. All experiments using animals were carried out under approval by the UCD Institutional Animals Care and Use Committee.

\section{Isolation of TGCs and mature sperm}

TGCs (Phelps et al. 1990, Nishimura et al. 2007) and mature sperm (Claassens et al. 1998, Nishimura et al. 2007) were isolated from $\sim 16$-week-old male mice. Briefly, for TGC preparation, cell suspensions containing all testicular cell types were obtained by thoroughly mincing testicles with razor blades, and TGCs were separated from the testicular cell suspensions on a $52 \%(\mathrm{v} / \mathrm{v})$ gradient of Percoll (GE Healthcare Life Sciences, Piscataway, NJ, USA). Mature sperm were released from the cauda epididymis and subsequently purified by using OptiPrep Density Gradient Medium (Sigma-Aldrich). To prepare protein extracts of TGCs or mature sperm, cells $\left(1 \times 10^{8}\right.$ cells $\left./ \mathrm{ml}\right)$ were suspended in PBS containing $1 \%(\mathrm{w} / \mathrm{v})$ $n$-octyl $\beta$-D-pyranoglucoside (PBS/OG) and incubated for $30 \mathrm{~min}$ on ice. After centrifugation of the suspensions at $20000 \mathrm{~g}$ for $10 \mathrm{~min}$ at $4{ }^{\circ} \mathrm{C}$, the supernatants were used for experiments.

We also used PBS/OG containing the EDTA-free Complete Protease Inhibitor Cocktail Tablets (Roche Applied Science) for extraction of TGC or sperm proteins. However, the protease inhibitor cocktail showed no significant effect on blocking the degradation of TMEM190 protein, which presumably occurred during the cellular protein extractions (data not shown). Therefore, all cell lysates used in this study were prepared in PBS/OG containing no protease inhibitors.

\section{RT-PCR}

Gene expression of Tmem190 was examined in various mouse tissues by RT-PCR, in which first-strand CDNAs of the tested tissues were used as templates for conventional PCR. Except for TGCs, all tested mouse tissues could be evaluated using various first-strand cDNAs that were contained in the Mouse Multiple Tissue cDNA Panel I Kit (Clontech Laboratories, Inc.).
To prepare first-strand cDNA of mouse TGCs, poly $(\mathrm{A})^{+} \mathrm{RNA}$ was purified from $1 \times 10^{8}$ TGCs with the FastTrack 2.0 mRNA Isolation Kit (Invitrogen Life Technologies). First-strand cDNA was then synthesized from $100 \mathrm{ng}$ of the mouse TGC poly $(A)^{+}$RNA with random primers in $20-\mu$ reaction mixtures by using the StrataScript First-Strand cDNA Synthesis Kit (Agilent Technology, Inc., formerly Stratagene, Santa Clara, CA, USA), according to the manufacturer's protocol.

PCR was carried out in $10-\mu$ reaction mixtures composed of $1 \times$ PCR buffer, $200 \mu \mathrm{mol} / \mathrm{I}$ dNTP mixture, $0.2 \mu \mathrm{mol} / \mathrm{l}$ forward primer, $0.2 \mu \mathrm{mol} / \mathrm{l}$ reverse primer, $1 \mu \mathrm{l}$ of first-strand cDNA, and $1 \times$ Advantage cDNA Polymerase Mix (Clontech). Primer sets used were $5^{\prime}$-AATGGAATCCAGGGATTTTTCTAC-3' (forward) and 5'-CTATTCTTCACСТCCTGTGTCC-3' (reverse) for Tmem 190 (435 bp), 5'-ATCGTCTCTCACTATTTGGAAATACAT-3' (forward) and 5'-TAAAATAATTGCAAGTGATTCCAGAGT-3' (reverse) for Adam2 (411 bp) (Kim et al. 2006), 5'-TAACAAAGAGAATTCTGAGGATAAAGA-3' (forward) and 5'-AAAGCCCTCCACAGCTAACGTCTTTGG-3' (reverse) for Adam3 (398 bp) (Kim et al. 2006), and 5'-TGAAGGTCGGAGTCAACGGATTTGGT-3' (forward) and 5'-CATGTGGGCCATGAGGTCCACCAC-3' (reverse) for Gapdh (983 bp) (Kim et al. 2006). Target cDNAs were amplified by one cycle of $94{ }^{\circ} \mathrm{C}$ for $3 \mathrm{~min}$, followed by 30 cycles of $94^{\circ} \mathrm{C}$ for $1 \mathrm{~min}, 65^{\circ} \mathrm{C}$ for $1 \mathrm{~min}$, and $72{ }^{\circ} \mathrm{C}$ for $1 \mathrm{~min}$, and one cycle of $72{ }^{\circ} \mathrm{C}$ for $10 \mathrm{~min}$. The resulting PCR products were separated by $0.8 \%$ $(\mathrm{w} / \mathrm{v})$ agarose gel electrophoresis.

\section{Antibodies}

Mouse MAB against mouse IZUMO1 ( $\alpha$-IZUMO1; IgM, clone OBF13; Okabe et al. 1987) was a gift of Dr M Okabe (Osaka University, Osaka, Japan). Affinity-purified mouse polyclonal antibody against mouse SPAM1/PH-20 was produced in our laboratory (Nishimura et al. 2001). Mouse MABs against mouse ADAM2 (IgG2b, clone 9D2.2) and ADAM3 (IgG1, clone 7C1.2) were provided by Chemicon/Millipore Corporation (Temecula, CA, USA). A mixture of two mouse MABs against GFP (IgG1, clones 7.1 and 13.1) was purchased from Roche, mouse MAB against $\alpha$-tubulin (IgG1, clone AA13) was from Sigma-Aldrich, HRP-conjugated goat anti-mouse IgM (molgM) ( $\mu$ chain) antibody was from Thermo Scientific (formerly Pierce Biotechnology; Rockford, IL, USA), and rblgG, normal molgM, and HRP-conjugated goat antibodies against rblgG and mouse IgG were from Santa Cruz Biotechnology, Inc. (Santa Cruz, CA, USA). Alexa Fluor 488-conjugated goat anti-molgM ( $\mu$ chain) antibody and Alexa Fluor 568-conjugated donkey anti-rblgG antibody, which were the secondary antibodies used for immunofluorescence, were purchased from Molecular Probes/Invitrogen (San Diego, CA, USA).

We prepared $\alpha$-TMEM190 as follows: a DNA fragment encoding the $\mathrm{N}$-terminal region of mouse TMEM190 (residues 22-80, N-TMEM190) was ligated into a pGEX-4T-1 vector (GE Healthcare). By using this expression vector, a glutathione S-transferase (GST)-tagged recombinant protein of N-TMEM190 (GST/N-TMEM190) was produced in the Escherichia coli strain BL21. GST/N-TMEM190 was purified on a column of GST.Bind Resin (Novagen/EMD Chemicals, Inc., Gibbstown, NJ, USA) and used for immunization 
of rabbits. For affinity purification of $\alpha$-TMEM190, the DNA fragment coding for N-TMEM190 was ligated into pET-23d (Novagen), and this vector was used to produce a recombinant protein of N-TMEM190 that is tagged at its C-terminal $6 \times$ His (N-TMEM190/His6) in the E. coli strain BL21 (DE3). The N-TMEM190/His6 protein was immobilized onto Sepharose 4B (GE Healthcare), incubated with raw $\alpha$-TMEM190 sera, and washed with PBS containing $500 \mathrm{mmol} / \mathrm{l} \mathrm{NaCl}$. $\alpha$-TMEM190 was eluted from the beads with $0.1 \mathrm{~mol} / \mathrm{l}$ glycine- $\mathrm{HCl}, \mathrm{pH} 2.5$, and immediately neutralized with one-ninth volume of $2 \mathrm{~mol} / \mathrm{l}$ Tris- $\mathrm{HCl}, \mathrm{pH}$ 9.0. The purified antibody was dialyzed against PBS prior to using in experiments.

\section{Immunoblotting}

SDS-PAGE using 14\% (w/v) Novex Tris-Glycine Gels (Invitrogen) was carried out under the reducing conditions, unless otherwise noted. Separated proteins were transferred onto Immobilon-P Transfer Membranes (Millipore, Bedford, MA, USA), followed by incubation of the membranes at room temperature for $1.5 \mathrm{~h}$ with $1 \mu \mathrm{g} / \mathrm{ml}$ primary antibodies and subsequently for $30 \mathrm{~min}$ with $50 \mathrm{ng} / \mathrm{ml}$ HRP-conjugated secondary antibodies. To capture biotinylated proteins, blots were incubated for $1.5 \mathrm{~h}$ at room temperature with $0.5 \mu \mathrm{g} / \mathrm{ml}$ High Sensitivity NeutrAvidin-HRP (Thermo Scientific). Immune or biotin-NeutrAvidin complexes were then detected by using the SuperSignal West Dura Extended Duration Substrate (Thermo Scientific) according to the manufacturer's instruction.

\section{Proteinase $K$ digestion of cell-surface proteins}

TGCs or cauda epididymal sperm of B6SJF1 mice were suspended in PBS $\left(1 \times 10^{8}\right.$ cells $\left./ \mathrm{ml}\right)$, and $90-\mu \mathrm{l}$ aliquots from each cell suspension were incubated with $10 \mu \mathrm{l}$ of various concentrations of proteinase $\mathrm{K}$ for $30 \mathrm{~min}$ at $37^{\circ} \mathrm{C}$. To terminate the proteinase $\mathrm{K}$ digestion, $2 \mu \mathrm{l}$ of $100 \mathrm{mmol} / \mathrm{I}$ phenylmethanesulfonyl fluoride (PMSF) was added, followed by additional incubation for $15 \mathrm{~min}$ at room temperature. The digested cell samples were washed three times with PBS by centrifugation at $800 \mathrm{~g}$ for $5 \mathrm{~min}$ at $4{ }^{\circ} \mathrm{C}$, suspended in $2 \mu \mathrm{l}$ of $100 \mathrm{mmol} / \mathrm{l} \mathrm{PMSF}$ plus $100 \mu \mathrm{l}$ of PBS/OG, and incubated for $30 \mathrm{~min}$ on ice. After centrifugation at $20000 \mathrm{~g}$ for $10 \mathrm{~min}$ at $4{ }^{\circ} \mathrm{C}$, the supernatants were used as 'cell suspension'. Similar experiments were also carried out using TGC or sperm protein extracts derived from B6SJF1 mice (equivalent to $1 \times 10^{8}$ cell $/ \mathrm{ml}$, see 'Isolation of TGCs and mature sperm' for preparation), instead of cell suspensions. In this case, reaction mixtures after the PMSF treatment to terminate proteinase $\mathrm{K}$ digestion were used as 'cell lysate'. Proteins that were contained in aliquots $(5.7 \mu \mathrm{l}$ for TGCs and $11.3 \mu \mathrm{l}$ for sperm) from 'cell suspension' or 'cell lysate' samples were analyzed by immunoblotting for SPAM1, ADAM2, GFP, or TMEM190.

\section{Subcellular fractionation of mature sperm}

Subcellular components of mature sperm were prepared according to the published methods (Honda et al. 2002, Kim et al. 2003, 2004) with slight modifications. Briefly, Al-sperm of B6SJF1 mice $\left(1 \times 10^{8}\right.$ sperm/ml) were incubated for $1 \mathrm{~h}$ at $37^{\circ} \mathrm{C}$ with $10 \mu \mathrm{mol} / \mathrm{l}$ calcium ionophore A23187 in Human Tubal Fluid (HTF) medium (without BSA, Irvine Scientific, Santa Ana, CA, USA). The sperm suspensions after the acrosome reaction were centrifuged at $800 \mathbf{g}$ for $5 \mathrm{~min}$ at room temperature to remove AR-sperm, and the supernatants were again centrifuged at $20000 \mathrm{~g}$ for $5 \mathrm{~min}$ at room temperature. The lowspeed supernatants were subjected to ultracentrifugation at $100000 \mathrm{~g}$ for $90 \mathrm{~min}$ at $4{ }^{\circ} \mathrm{C}$, and the resulting high-speed supernatants included proteins released during the acrosome reaction plus soluble acrosomal contents (RPA). The pellets obtained by ultracentrifugation were washed once with PBS and suspended in PBS/OG to prepare protein extracts (for preparation, see 'Isolation of TGCs and mature sperm'). The extracts were then used as a fraction of the PM and OAM that had been fused to each other during the acrosome reaction (PM/OAM). AR-sperm, obtained by centrifugation after the incubation of AI-sperm with A23187, were washed three times with PBS, resuspended in PBS $\left(1 \times 10^{8}\right.$ cells $\left./ \mathrm{ml}\right)$, and sonicated to detach their tails from the sperm heads. Fractions of the AR-sperm heads (ARH) and tails (ART) were subsequently separated on a sucrose density gradient. Proteins in each subcellular fraction (equivalent to $1 \times 10^{6}$ sperm) were analyzed by immunoblotting for ADAM2, GFP, or TMEM190.

\section{Immunofluorescence}

TGCs were isolated from CD1 mice and suspended $\left(0.5 \times 10^{7}\right.$ cells/ml) in HEPES-buffered saline containing $\mathrm{Mg}^{2+}$ (Phelps et al. 1990, Nishimura et al. 2007). Ten- $\mu$ aliquots from the TGC suspensions were placed as $\sim 1-\mathrm{cm}$ spots onto coverslips that had been coated by poly-L-lysine and allowed to stand at room temperature for $\sim 10 \mathrm{~min}$ until the edge of each spot became dried. The cell samples were then fixed in methanol for $15 \mathrm{~min}$ at $-20^{\circ} \mathrm{C}$, followed by washing three times with PBS. As for sperm samples, AI- or AR-sperm (for preparation, see 'Subcellular fractionation of mature sperm') of CD1 mice were washed three times with PBS at $800 \mathrm{~g}$ for $5 \mathrm{~min}$ at room temperature, suspended $\left(1 \times 10^{7} \mathrm{sperm} / \mathrm{ml}\right)$ in PBS containing 4\% (w/v) paraformaldehyde (PBS/PFA), and incubated for $30 \mathrm{~min}$ on ice to allow these sperm samples to be fixed. After washing three times with PBS, sperm were resuspended in PBS $\left(0.5 \times 10^{7}\right.$ sperm $\left./ \mathrm{ml}\right)$, placed onto polyL-lysine-coated coverslips (5- $\mu$ l sperm suspension/spot), and kept for $\sim 15 \mathrm{~min}$ at room temperature until the sperm became completely dried. The sperm spots were then washed three times with PBS. The cell spots of TGCs, Al-sperm, or AR-sperm that had been fixed followed by washing with PBS were incubated for $30 \mathrm{~min}$ at room temperature in $100 \mu \mathrm{l}$ of PBS containing $3 \%(\mathrm{w} / \mathrm{v})$ BSA (PBSA) or PBSA containing $0.1 \%(\mathrm{v} / \mathrm{v})$ TX100 (PBSAT) and then washed once with PBS. The cells were subsequently incubated for $1 \mathrm{~h}$ at room temperature in $100 \mu \mathrm{l}$ of PBSA containing $10 \mu \mathrm{g} / \mathrm{ml}$ Alexa Fluor 488-conjugated PNA (Molecular Probes) and/or $5 \mu \mathrm{g} / \mathrm{ml}$ rblgG or $\alpha$-TMEM190 and/or $5 \mu \mathrm{g} / \mathrm{ml}$ molgM or $\alpha$-IZUMO1. After washing three times with PBS containing $0.1 \%(\mathrm{v} / \mathrm{v})$ TX100 (PBST), the cells were incubated for $30 \mathrm{~min}$ at room temperature in $100 \mu \mathrm{l}$ of PBSAT containing $5 \mu \mathrm{g} / \mathrm{ml}$ 4',6-diamino-2-phenylindole (DAPI) and $10 \mu \mathrm{g} / \mathrm{ml}$ Alexa 
Fluor 568-labeled donkey anti-rblgG antibody and/or $10 \mu \mathrm{g} / \mathrm{ml}$ Alexa Fluor 488-labeled goat anti-molgM antibody. After the cell-bearing coverslips were washed three times with PBST and twice with PBS, one drop of the ProLong antifade reagent (Invitrogen) was put onto each cell spot. The cell samples were then observed under the FluoView FV1000 Confocal Microscope (Olympus America, Inc., Center Valley, PA, USA).

\section{Immunoprecipitation}

Protein extracts of TGCs, Al-sperm, and AR-sperm from CD1 mice (total) were prepared as described in 'Isolation of TGCs and mature sperm'. Cell-surface protein fractions of AR-sperm (surface) were prepared as previously reported (Nishimura et al. 2007). Briefly, AR-sperm $\left(0.5 \times 10^{8} \mathrm{sperm} / \mathrm{ml}\right)$ were incubated for $30 \mathrm{~min}$ at room temperature with $1 \mathrm{mmol} / \mathrm{l}$ EZ-Link Sulfo-NHS-LC-Biotin (Thermo Scientific) in $2 \mathrm{ml}$ of HTF medium. After washing three times with PBS, the biotinylated AR-sperm were suspended in $1 \mathrm{ml}$ of PBS/OG to prepare protein extracts. To isolate biotinylated proteins, the cell lysates (equivalent to $1 \times 10^{8}$ sperm) were incubated for $30 \mathrm{~min}$ at room temperature with $100 \mu \mathrm{l}$ of $50 \%(\mathrm{v} / \mathrm{v})$ slurry of Monomeric Avidin Agarose (Thermo Scientific) in $2 \mathrm{ml}$ of PBS/ OG containing $500 \mathrm{mmol} / \mathrm{l} \mathrm{NaCl}$ (Binding Buffer). The beads were washed three times with Binding Buffer, suspended in $200 \mu \mathrm{l}$ of $5 \mathrm{mmol} / \mathrm{I}$ D-biotin in the same buffer, and incubated for $30 \mathrm{~min}$ at room temperature to allow biotinylated proteins to be eluted from the monomeric avidin-beads. Following centrifugation at $500 \mathrm{~g}$ for $5 \mathrm{~min}$ at room temperature, the supernatants containing AR-sperm surface proteins were used as 'surface' fraction. To confirm that only cell-surface proteins are biotinylated, 'total' and 'surface' fractions of AR-sperm with or without biotinylation were subjected to immunoblotting for ADAM2 or $\alpha$-tubulin.

For immunoprecipitation, 'total' or 'surface' samples (equivalent to $2.5 \times 10^{7}$ cells) were incubated for $2 \mathrm{~h}$ on ice in $1 \mathrm{ml}$ of Binding Buffer containing $25 \mu \mathrm{l}$ of $50 \%(\mathrm{v} / \mathrm{v})$ slurry of Sepharose 4B-beads where rblgG or $\alpha$-TMEM190 was immobilized ( $\sim 2 \mathrm{mg} \operatorname{lgG} / \mathrm{ml}$ beads). After washing three times with Binding Buffer, the beads were suspended in $62.5 \mu \mathrm{l}$ of $0.2 \mathrm{~mol} / \mathrm{l}$ glycine- $\mathrm{HCl}, \mathrm{pH} 2.5$, containing $1 \%$ $(\mathrm{w} / \mathrm{v}) \mathrm{OG}$, and incubated for $15 \mathrm{~min}$ at room temperature. The suspensions were then centrifuged at $500 \boldsymbol{g}$ for $5 \mathrm{~min}$ at room temperature, and their supernatants containing mouse TMEM190 and its associated proteins were mixed with onefourth volume of $2 \mathrm{~mol} / \mathrm{l}$ Tris- $\mathrm{HCl}, \mathrm{pH} 9.0$, to neutralize the supernatant solutions. Proteins in the immunoprecipitated fractions were analyzed by immunoblotting for TMEM190, IZUMO1, or biotinylated proteins.

\section{Creation of Tmem190-null mice}

The mouse genomic clone bMQ-202C5, including the Tmem190 gene, was obtained from the Wellcome Trust Sanger Institute (Cambridge, UK). To construct a targeting vector, 2.2- and 6.3-kbp DNA fragments that correspond to $5^{\prime}$ - and 3'-flanking regions of Tmem190 respectively were excised from the bMQ-202C5 DNA. These two fragments and an expression cassette of the neomycin-resistance gene (neo) were then ligated together into a pBluescript II SK(+) vector (Agilent Technology). After the targeting vector that had been linearized by Kpnl digestion was electroporated into mouse embryonic stem (ES) cells, homologous recombinants were selected by using G418. By PCR screening (for details, see 'PCR screening'), seven ES cell clones carrying the targeted mutation in the Tmem190 gene were identified among 96 G418-resistant clones and subsequently injected into $\mathrm{C} 57 \mathrm{BL} / 6$ mouse blastocysts. The resulting chimeric male mice were crossed to $\mathrm{C} 57 \mathrm{BL} / 6$ female mice to obtain heterozygous mutant progeny for the Tmem190 gene. Homozygous mutant mice were obtained by mating of heterozygous males and females.

\section{PCR screening}

Tmem190 genotypes of ES cell clones or mice were determined by PCR. Primer sets used were as follows: 5'-TTCСССТССССАТСТTТСАССАСТ-3' (FW, forward) and 5'-TCTGCTTTAGGGAACACAGACCAG-3' (WTRV, reverse) for the wild-type locus, and the FW primer (forward) and 5'-GACCGCTTCCTCGTGCTTTACGGT-3' (NeoRV, reverse) for the mutant locus. Template genomic DNA samples were prepared from ES cells or mouse tails, according to the published method (Aljanabi \& Martinez 1997). PCR mixtures $(20 \mu \mathrm{l})$ were composed of $1 \times$ PCR buffer, $200 \mu \mathrm{mol} / \mathrm{I} \mathrm{dNTP}$ mixture, $0.2 \mu \mathrm{mol} / \mathrm{l}$ forward primer, $0.2 \mu \mathrm{mol} / \mathrm{l}$ reverse primer, $\sim 100 \mathrm{ng}$ of genomic DNA, and $1 \times$ Advantage cDNA Polymerase Mix. The PCRs were subjected to one cycle of $94{ }^{\circ} \mathrm{C}$ for $3 \mathrm{~min}$, followed by 32 cycles of $94{ }^{\circ} \mathrm{C}$ for $1 \mathrm{~min}, 65^{\circ} \mathrm{C}$ for $1 \mathrm{~min}$, and $72{ }^{\circ} \mathrm{C}$ for $3 \mathrm{~min}$, and one cycle of $72{ }^{\circ} \mathrm{C}$ for $10 \mathrm{~min}$. Amplified DNAs were then subjected to $0.8 \%(\mathrm{w} / \mathrm{v})$ agarose gel electrophoresis.

\section{In vivo fertility test}

Each tested male (8-16 weeks old) was placed with two C57BL/6 females (6-8 weeks old) in a cage, while two tested females were crossed to one C57BL/6 male. Once a day, every female was checked for the vaginal plug formation, and plugpositive females were individually transferred into new cages. After $\sim 20$ days, the numbers of pups born were counted to compare in vivo fertility of Tmem190-null mice with that of wild-type mice.

\section{Declaration of interest}

The authors declare that there is no conflict of interest that could be perceived as prejudicing the impartiality of the research reported.

\section{Funding}

This study was supported by grants from the National Institute of Child Health and Human Development (NICHD) to D G Myles (HD16580) and to D G Myles and P Primakoff (U54-29125). 


\section{Acknowledgements}

We thank Dr G L Gerton (University of Pennsylvania, Philadelphia, PA, USA) for the mouse line B6SJF1 and Dr M Okabe (Osaka University, Osaka, Japan) for the anti-mouse IZUMO1 MAB OBF13. We are also grateful to Dr S W L'Hernault (Emory University, Atlanta, GA, USA) for valuable comments on our manuscript and A Latour (University of North Carolina, Chapel Hill, NC, USA) for transfection of our targeting vector into ES cells and injection of ES cell clones into blastocysts.

\section{References}

Alfalah M, Jacob R, Preuss U, Zimmer KP, Naim H \& Naim HY 1999 $O$-linked glycans mediate apical sorting of human intestinal sucraseisomaltase through association with lipid rafts. Current Biology 9 593-596. (doi:10.1016/S0960-9822(99)80263-2)

Aljanabi SM \& Martinez I 1997 Universal and rapid salt-extraction of high quality genomic DNA for PCR-based techniques. Nucleic Acids Research 25 4692-4693. (doi:10.1093/nar/25.22.4692)

Baibakov B, Gauthier L, Talbot P, Rankin TL \& Dean J 2007 Sperm binding to the zona pellucida is not sufficient to induce acrosome exocytosis. Development 134 933-943. (doi:10.1242/dev.02752)

Claassens OE, Menkveld R \& Harrison KL 1998 Evaluation of three substitutes for Percoll in sperm isolation by density gradient centrifugation. Human Reproduction 13 3139-3143. (doi:10.1093/humrep/ 13.11.3139)

Conner SJ, Lefievre L, Hughes DC \& Barratt CL 2005 Cracking the egg: increased complexity in the zona pellucida. Human Reproduction 20 1148-1152. (doi:10.1093/humrep/deh835)

Dean J 2007 The enigma of sperm-egg recognition in mice. Society of Reproduction and Fertility Supplement 63 359-365.

Fang J, Rohloff P, Miranda K \& Docampo R 2007 Ablation of a small transmembrane protein of Trypanosoma brucei (TbVTC1) involved in the synthesis of polyphosphate alters acidocalcisome biogenesis and function, and leads to a cytokinesis defect. Biochemical Journal $\mathbf{4 0 7}$ 161-170. (doi:10.1042/BJ20070612)

Freeman-Cook LL \& Dimaio D 2005 Modulation of cell function by small transmembrane proteins modeled on the bovine papillomavirus E5 protein. Oncogene 24 7756-7762. (doi:10.1038/sj.onc.1209039)

Fujihara Y, Murakami M, Inoue N, Satouh Y, Kaseda K, Ikawa M \& Okabe M 2010 Sperm equatorial segment protein 1, SPESP1, is required for fully fertile sperm in mouse. Journal of Cell Science 123 1531-1536. (doi:10.1242/jcs.067363)

Gahlay G, Gauthier L, Baibakov B, Epifano O \& Dean J 2010 Gamete recognition in mice depends on the cleavage status of an egg's zona pellucida protein. Science 329 216-219. (doi:10.1126/science. 1188178)

Gil GC, Velander WH \& Van Kott KE 2009 N-glycosylation of microheterogeneity and site occupancy of an Asn-X-Cys sequon in plasma derived and recombinant protein C. Proteomics 9 2555-2567. (doi:10.1002/pmic.200800775)

Grzmil P, Kim Y, Shamsadin R, Neesen J, Adham IM, Heinlein UA, Schwarzer UJ \& Engel W 2001 Human cyritestin genes (CYRN1 and CYRN2) are non-functional. Biochemical Journal 357 551-556. (doi:10. 1042/0264-6021:3570551)

Hoffmann W \& Hauser F 1993 The P-domain or trefoil motif: a role in renewal and pathology of mucous epithelia? Trends in Biochemical Sciences 18 239-243. (doi:10.1016/0968-0004(93)90170-R)

Honda A, Yamagata K, Sugiura S, Watanabe K \& Baba T 2002 A mouse serine protease TESP5 is selectively included into lipid rafts of sperm membrane presumably as a glycosylphosphatidylinositol-anchored protein. Journal of Biological Chemistry 277 16976-16984. (doi:10. 1074/jbc.M112470200)

Ikawa M, Inoue N \& Okabe M 2008 Mechanisms of sperm-egg interactions emerging from gene-manipulated animals. International Journal of Developmental Biology 52 657-664. (doi:10.1387/ijdb.072529mi)
Inoue N, Ikawa M, Isotani A \& Okabe M 2005 The immunoglobulin superfamily protein Izumo is required for sperm to fuse with eggs. Nature 434 234-238. (doi:10.1038/nature03362)

Inoue N, Yamaguchi R, Ikawa M \& Okabe M 2007 Sperm-egg interaction and gene manipulated animals. Society of Reproduction and Fertility Supplement 65 363-371.

Ito C, Yamatoya K, Yoshida K, Maekawa M, Miyado K \& Toshimori K 2010 Tetraspanin family protein CD9 in the mouse sperm: unique localization, appearance, behavior and fate during fertilization. Cell Tissue Research 340 583-594. (doi:10.1007/s00441-010-0967-7)

Jury JA, Frayne J \& Hall L 1997 The human fertilin alpha gene is nonfunctional: implications for its proposed role in fertilization. Biochemical Journal 321 577-581.

Kaji K, Oda S, Shikano T, Ohnuki T, Uematsu Y, Sakagami J, Tada N, Miyazaki S \& Kudo A 2000 The gamete fusion process is defective in eggs of Cd9-deficient mice. Nature Genetics 24 279-282. (doi:10.1038/ 73502)

Kawai Y, Hama T, Mayumi T, Okabe M, Matzno S, Kohama Y \& Mimura T 1989 Flow cytometric analysis of mouse sperm using monoclonal antisperm antibody OBF13. Journal of Reproductive Immunology 16 71-82. (doi:10.1016/0165-0378(89)90007-7)

Kim KS \& Gerton GL 2003 Differential release of soluble and matrix components: evidence for intermediate states of secretion during spontaneous acrosomal exocytosis in mouse sperm. Developmental Biology 264 141-152. (doi:10.1016/j.ydbio.2003.08.006)

Kim E, Nishimura H \& Baba T 2003 Differential localization of ADAM1a and ADAM1b in the endoplasmic reticulum of testicular germ cells and on the surface of epididymal sperm. Biochemical and Biophysical Research Communications 304 313-319. (doi:10.1016/S0006-291X(03) 00588-6)

Kim E, Nishimura H, Iwase S, Yamagata K, Kashiwabara S \& Baba T 2004 Synthesis, processing, and subcellular localization of mouse ADAM3 during spermatogenesis and epididymal sperm transport. Journal of Reproduction and Development 50 571-578. (doi:10.1262/jrd.50.571)

Kim T, Oh J, Woo JM, Choi E, Im SH, Yoo YJ, Kim DH, Nishimura H \& Cho C 2006 Expression and relationship of male reproductive ADAMs in mouse. Biology of Reproduction 74 744-750. (doi:10.1095/biolreprod. 105.048892)

Kjellev S 2009 The trefoil factor family - small peptides with multiple functionalities. Cellular and Molecular Life Sciences 66 1350-1369. (doi:10.1007/s00018-008-8646-5)

Lai CC, Edwards AP \& DiMaio D 2005 Productive interaction between transmembrane mutants of the bovine papillomavirus E5 protein and the platelet-derived growth factor beta receptor. Journal of Virology $\mathbf{7 9}$ 1924-1929. (doi:10.1128/JVI.79.3.1924-1929.2005)

Le Naour F, Rubinstein E, Jasmin C, Prenant M \& Boucheix C 2000 Severely reduced female fertility in CD9-deficient mice. Science 287 319-321. (doi:10.1126/science.287.5451.319)

Litscher ES, Williams Z \& Wassarman PM 2009 Zona pellucida glycoprotein ZP3 and fertilization in mammals. Molecular Reproduction and Development 76 933-941. (doi:10.1002/mrd.21046)

Makarova O, Roh MH, Liu CJ, Laurinec S \& Margolis B 2003 Mammalian Crumbs 3 is a small transmembrane protein linked to protein associated with Lin-7 (Pals1). Gene 302 21-29. (doi:10.1016/S0378 111902010843)

Miyado K, Yamada G, Yamada S, Hasuwa H, Nakamura Y, Ryu F, Suzuki K, Kosai K, Inoue K, Ogura A et al. 2000 Requirement of CD9 on the egg plasma membrane for fertilization. Science 287 321-324. (doi:10.1126/ science.287.5451.321)

Nishimura H, Cho C, Branciforte DR, Myles DG \& Primakoff P 2001 Analysis of loss of adhesive function in sperm lacking cyritestin or fertilin beta. Developmental Biology 233 204-213. (doi:10.1006/dbio.2001. 0166)

Nishimura H, Kim E, Nakanishi T \& Baba T 2004 Possible function of the ADAM1a/ADAM2 fertilin complex in the appearance of ADAM3 on the sperm surface. Journal of Biological Chemistry 279 34957-34962. (doi:10.1074/jbc.M314249200)

Nishimura H, Myles DG \& Primakoff P 2007 Identification of an ADAM2ADAM3 complex on the surface of mouse testicular germ cells and cauda epididymal sperm. Journal of Biological Chemistry 282 17900-17907. (doi:10.1074/jbc.M702268200) 
Okabe M \& Cummins JM 2007 Mechanisms of sperm-egg interactions emerging from gene-manipulated animals. Cellular and Molecular Life Sciences 64 1945-1958. (doi:10.1007/s00018-007-7037-7)

Okabe M, Adachi T, Takada K, Oda H, Yagasaki M, Kohama Y \& Mimura T 1987 Capacitation-related changes in antigen distribution on mouse sperm heads and its relation to fertilization rate in vitro. Journal of Reproductive Immunology 11 91-100. (doi:10.1016/0165-0378(87) 90014-3)

Otto B \& Wright N 1994 Trefoil peptides. Coming up clover. Current Biology 4 835-838. (doi:10.1016/S0960-9822(00)00186-X)

Phelps BM, Koppel DE, Primakoff P \& Myles DG 1990 Evidence that proteolysis of the surface is an initial step in the mechanism of formation of sperm cell surface domains. Journal of Cell Biology 111 1839-1847. (doi:10.1083/jcb.111.5.1839)

Rivard CJ, Almeida NE, Berl T \& Capasso JM 2005 The gamma subunit of $\mathrm{Na} / \mathrm{K}-A T P a s e:$ an exceptional, small transmembrane protein. Frontiers in Bioscience 10 2604-2610. (doi:10.2741/1724)

Roh MH, Fan S, Liu CJ \& Margolis B 2003 The Crumbs3-Pals1 complex participates in the establishment of polarity in mammalian epithelial cells. Journal of Cell Science 116 2895-2906. (doi:10.1242/ jcs.00500)

Rojo M, Emery G, Marjomaki V, McDowall AW, Parton RG \& Gruenberg J 2000 The transmembrane protein p23 contributes to the organization of the Golgi apparatus. Journal of Cell Science 113 1043-1057.

Sato C, Kim JH, Abe Y, Saito K, Yokoyama S \& Kohda D 2000 Characterization of the $\mathrm{N}$-oligosaccharides attached to the atypical Asn-X-Cys sequence of recombinant human epidermal growth factor receptor. Journal of Biochemistry 127 65-72.

Shamsadin R, Adham IM, Nayernia K, Heinlein UA, Oberwinkler H \& Engel W 1999 Male mice deficient for germ-cell cyritestin are infertile. Biology of Reproduction 61 1445-1451. (doi:10.1095/biolreprod61.6. 1445)

Shastry BS 1995 Genetic knockouts in mice: an update. Experientia $\mathbf{5 1}$ 1028-1039. (doi:10.1007/BF01946911)
Sosnik J, Miranda PV, Spiridonov NA, Yoon SY, Fissore RA, Johnson GR \& Visconti PE 2009 Tssk6 is required for Izumo relocalization and gamete fusion in the mouse. Journal of Cell Science 122 2741-2749. (doi:10. 1242/jcs.047225)

Spodsberg N, Alfalah M \& Naim HY 2001 Characteristics and structural requirements of apical sorting of the rat growth hormone through the O-glycosylated stalk region of intestinal sucrase-isomaltase. Journal of Biological Chemistry 276 46597-46604. (doi:10.1074/jbc.M108187200)

Stein KK, Go JC, Lane WS, Primakoff P \& Myles DG 2006 Proteomic analysis of sperm regions that mediate sperm-egg interactions. Proteomics 6 3533-3543. (doi:10.1002/pmic.200500845)

Vance BA, Bennett MJ, Ward Y, Gress RG \& Kearse KP 1999 Distinct but dispensable $\mathrm{N}$-glycosylation of human CD69 proteins. Archives of Biochemistry and Biophysics 368 214-220. (doi:10.1006/abbi.1999.1322)

Wassarman PM \& Litscher ES 2009 The multifunctional zona pellucida and mammalian fertilization. Journal of Reproductive Immunology $\mathbf{8 3}$ 45-49. (doi:10.1016/j.jri.2009.06.259)

Yamashita M, Yamagata K, Tsumura K, Nakanishi T \& Baba T 2007 Acrosome reaction of mouse epididymal sperm on oocyte zona pellucida. Journal of Reproduction and Development 53 255-262. (doi:10.1262/jrd.18145)

Yanagimachi R 1994 Mammalian fertilization. In The Physiology of Reproduction, 2nd edn, pp 189-317. Eds E Knobil \& JD Neill. New York: Raven Press.

Zickermann V, Angerer H, Ding MG, Nubel E \& Brandt U 2010 Small single transmembrane domain (STMD) proteins organize the hydrophobic subunits of large membrane protein complexes. FEBS Letters $\mathbf{5 8 4}$ 2516-2525. (doi:10.1016/j.febslet.2010.04.021)

Received 14 September 2010

First decision 29 October 2010

Revised manuscript received 22 December 2010

Accepted 27 January 2011 